\title{
Yield Evaluation of a Wheat Line with Combined Resistance to Russian Wheat Aphid and Stem Rust Race "Ug99" in Kenya
}

\author{
F. O. Amulaka ${ }^{1}$, J. N. Maling'a ${ }^{3}$, R. S. Pathak ${ }^{1}$, M. Cakir ${ }^{2}$, R. M. S. Mulwa ${ }^{{ }^{*}}$ \\ ${ }^{1}$ Egerton University, Department of Crops, Horticulture and Soils, Egerton, Kenya; ${ }^{2}$ Murdoch University, Perth, Australia; ${ }^{3}$ Kenya \\ Agricultural Research Institute (KARI), Njoro, Kenya. \\ Email: ${ }^{*}$ rmulwa@egerton.ac.ke
}

Received January $27^{\text {th }}, 2013$; revised May $17^{\text {th }}, 2013$; accepted June $18^{\text {th }}, 2013$

Copyright (C) 2013 F. O. Amulaka et al. This is an open access article distributed under the Creative Commons Attribution License, which permits unrestricted use, distribution, and reproduction in any medium, provided the original work is properly cited.

\begin{abstract}
In Kenya, Russian wheat aphid (RWA) and stem rust race TTKS ("Ug99") are the most devastating pests of wheat. Severe infestations by RWA result in yield losses of up to $90 \%$ while epidemics of "Ug99" can cause up to $100 \%$ loss. The two pests combined have seriously affected farmer incomes forcing them to rely heavily on pesticides and increasing the cost of production. This study sought to evaluate a wheat line that has been developed to be resistant to both RWA and "Ug99" by pyramiding two major resistance genes. Three varieties were used in this study: "Kwale", a Kenyan high yielding commercial variety but susceptible to both RWA and "Ug99"; "Cook", an Australian variety carrying stem rust resistance gene Sr36 conferring immunity to "Ug99"; and "KRWA9", a Kenyan line resistant to RWA but with poor agronomic attributes. The $\mathrm{F}_{1}$ of the double cross $\left(\mathrm{DC} \mathrm{F}_{1}\right)$ was obtained by crossing the $\mathrm{F}_{1}$ of "Kwale $\times$ Cook" and the $\mathrm{F}_{1}$ of "Kwale $\times \mathrm{KRWA9".} \mathrm{The} \mathrm{DC} \mathrm{F}_{1}$ population was subjected to sequential screening for both RWA and "Ug99" resistance. The surviving DC $F_{1}$ progenies were left to self pollinate in the field to obtain the DC $F_{2}$. The DC $F_{2}$ progenies were sequentially screened against RWA and "Ug99" to obtain a resistant population to both RWA and "Ug99". The yield and yield components of the new resistant line were compared with the three parents. Results showed that the $\mathrm{DC} \mathrm{F}_{2: 3}$ had higher yields than the three parents based on 1000 kernel weight, weight of kernel per spike, and the actual yield in tons/ha, indicating that the genes were successfully introgressed. It is concluded that though races with virulence for Sr36 have been reported, the gene provides immunity to race "Ug99" and can be used as a component for "Ug99" resistance breeding together with other $\mathrm{Sr}$ genes.
\end{abstract}

Keywords: Rusian Wheat Aphid; Stem Rust “Ug99”; Gene Pyramiding; Combined Resistance

\section{Introduction}

Russian wheat aphid (RWA), Diuraphis noxia (Kurdjumov), is one of the most noxious pests of cereal crops throughout the world [1]. Since its introduction in the USA in 1986, the economic losses were in excess of US $\$ 900$ million by 1994 [2]. In South Africa, yield losses due to RWA were reported to range from $21 \%$ to $92 \%$ [3]. RWA is a recent pest in Kenya, first identified in farmers' fields in 1995 [4]. It then spread quickly to all the wheat growing areas of the country and became evident that all the commercial wheat varieties in the country were susceptible [5]. In Kenya it has been reported to cause yield losses of up to $90 \%$ [6].

\footnotetext{
${ }^{*}$ Corresponding author.
}

The Russian wheat aphid is pale to light green in color with an elongated, spindle shaped body and grows up to $2 \mathrm{~mm}$ long. It has short antennae with rounded, very short, nearly invisible cornicles. The feature that easily distinguishes it from other cereal aphids is the presence of an appendage (supra-caudal process) above the cauda, giving the aphid the appearance of having two tails [7]. Two RWA biotypes have been reported in South Africa and USA [8] and at least two biotypes are thought to exist in Kenya [9]. These biotypes appear different from those found in South Africa and USA. Two wheat genotypes "KRWA9" and "KRWA16" have been found to be resistant to the local RWA biotypes conferred by two non-allelic RWA resistance genes [10,11].

RWA feeds on wheat from seedling stage until the 
plant is mature and can often be found in developing heads. When wheat plants die in response to heavy aphid feeding, the third and fourth instar aphids develop wings [12]. RWA feeds on the newest growth on the plant and effectively cause cessation of chlorophyll production in those leaves. It is believed that RWA injects toxins into the plants during feeding, preventing the production of chlorophyll and causing leaf curls [13]. The leaf curls create an enclosure that protects the insect from climatic vagaries, natural enemies, and insecticides. Symptoms of RWA damage include reduced plant height, sterile heads, low kernel weight, white, yellow or purple longitudinal streaks on the leaf and in the most severe condition, death [14].

Stem rust or black rust of wheat is caused by the fungal pathogen, Puccinia graminis Pers. f.sp. tritici. The host range of this form of Puccinia graminis is inconsistently reported in the literature but it is fairly wide (up to 28 species), with its main asexual host being wheat (Triticum spp.). Other cereals and a range of grasses can also become infected. The fungus completes its sexual cycle on the broad-leaved hosts, Berberis spp. and $M a-$ honia spp. Infected areas are rough to the touch. The red rust or summer spore stage appears on leaves and stems as elongate pustules (uredia) containing reddish brown spore masses. The black rust or autumn spore stage (teliospores) is similar except for color [15].

Historically, stem rust has caused massive yield losses of wheat wherever it occurred, but in the last 50 years the disease has not been of great concern because it has been effectively controlled through selection and breeding for stem rust resistance genes known as $\mathrm{Sr}$ genes [16]. In 1999 in Uganda, a new virulent stem rust race named "Ug99" was found on wheat lines known to have the stem rust resistance gene $S r 31$, a gene for which no virulence had been reported previously anywhere in the world. Similar virulence was observed in 2001 in Kenya and in 2003 in Ethiopia [17]. The new race ("Ug99") blocks the vascular tissues in cereal grains including wheat, oats and barley. It is highly damaging to wheat production causing yield losses upwards of 71\% [16]. Unlike leaf or stripe rusts that may reduce crop yields, "Ug99"-infected plants may suffer up to $100 \%$ loss [18]. According to FAO, an estimated $80 \%$ of the wheat varieties currently being grown in the East African region are susceptible to "Ug99". There is every reason to believe the new "Ug99" strain of stem rust represents a much greater risk to world wheat production with annual losses of as much as US $\$ 3$ billion in Africa, the Middle East and south Asia alone being possible [16]. If not controlled, stem rust race "Ug99" will have a major impact on food security, especially since global wheat stocks are at their historic low. The importance of "Ug99" was rec- ognized around 2005 when Dr. Norman Borlaug raised the alarm warning the world about the serious threat this starin of stem rust could pose to food security if proper actions were not instituted [19]. This warning elicited a global wheat research community response under the banner of the Borlaug Global Rust Initiative (http://www. globalrust.org). Kenya is one country deeply involved in the initiative following the appreciation of the fact that all commercial wheat varieties in grown are susceptible to race "Ug99". Serious wheat research efforts are focused on control of stem rust "Ug99" and RWA. From 2005-2010 over 200,000 wheat varieties, germplasm collections and advanced breeding materials were screened for resistance to "Ug99" and its derivative races at KARI-Njoro and at Kuluma and Debre in Ethiopia [20, 21]. A few accessions have been found to possess acceptable levels of resistance against "Ug99". Apart from conventional breeding research for resistance, recent and current efforts are focused on the development of linked molecular markers for the known resistance genes to allow for more efficient gene pyramiding [22]. The identification of new sources of resistance and dissociating negative traits associated with alien-derived resistances are also crucial efforts under investigation to mitigate the "Ug99" challenge [23,24].

On the basis of the foregoing, efforts are underway to develop wheat varieties that are resistant to both RWA and stem rust "Ug99" varieties to avert a catastrophic wheat industry crash in the region. This study was therefore conceived to evaluate the performance of wheat germplasm that has been developed to express combined resistance to both RWA and stem rust race "Ug99".

\section{Materials and Methods}

\subsection{Research Site}

The experiment was carried out in a breeding cage and open field at Kenya Agricultural Research Institute (KARI) at Njoro, Kenya. The station is located at an altitude of $2185 \mathrm{~m}$ a.s.l. and it lies between latitude $0^{\circ} 20^{\prime} \mathrm{S}$ and $35^{\circ} 56^{\prime} \mathrm{E}$. The area receives an average rainfall of 939 $\mathrm{mm}$ per annum, with a mean temperature of $14.9^{\circ} \mathrm{C}$. The site is classified as a Lower Highland 2 to 3 (LH2-LH3) agro ecological zone and has a sub humid modified tropical climate. The soil type is predominantly mollic andosols [25].

\subsection{Plant Materials}

The RWA and "Ug99" resistant plant materials were obtained from the breeding department of KARI-Njoro. Three varieties of wheat were used in this experiment: "Kwale", a Kenyan commercial variety known to be high yielding but susceptible to both RWA and "Ug99"; 
"Cook", an Australian variety carrying stem rust resistance gene Sr36 known to confer immunity to "Ug99" at both seedling and adult plant stages; and "KRWA9", a Kenyan line known to be resistant to RWA but has poor agronomic attributes. The $\mathrm{F}_{1}$ of the double cross $\left(\mathrm{DC} \mathrm{F}_{1}\right)$ used was obtained by crossing the $F_{1}$ of "Kwale $\times$ Cook" and the $F_{1}$ of "Kwale $\times$ KRWA9". The DC $F_{1}$ population was subjected to sequential screening for both RWA and "Ug99" resistance and the surviving DC F 1 progenies left to self pollinate to obtain the $\mathrm{DC} \mathrm{F}_{2}$. The $\mathrm{DC} \mathrm{F}_{2}$ progenies were sequentially screened against RWA and "Ug99" to obtain a population that is resistant to both RWA and "Ug99".

\subsection{Yield Evaluation}

Yield evaluation studies measured the yield and yield components of the developed line (the homozygous resistant $\mathrm{DC} \mathrm{F}_{2: 3}$ plants), and compared them with the parents. Four yield parameters were measured: 1000 kernel weight, weight of kernel per spike, number of effective tillers/plant and the actual yield in tons/ha. The number of days to $50 \%$ flowering, days to maturity, RWA damage score (scale: 1 - 9) and stem rust severity index (\%) were also recorded.

The experiment was repeated twice in a Randomized Complete Block Design (RCBD) with four treatments replicated three times. The four treatments were the parents ("Kwale", "Cook", "KRWA9") and the DC F $F_{2: 3}$ germplasm. All data were analyzed by ANOVA and means separated by the least significant difference (LSD) at $\mathrm{P} \leq 0.05$ using the SAS statistical programme version 12.

\section{Results and Discussion}

\subsection{Thousand Kernel Weight}

Thousand kernel weight is one of the most important yield components used to determine grain density. The overall means for 1000 kernel weight of the three parents and the $\mathrm{DC} \mathrm{F}_{2: 3}$ progenies are presented in Table 1. Generally all the parents "Kwale", "KRWA9" and "Cook" recorded low means of 1000 kernel weights ("Kwale" = $17.73 \mathrm{~g}$, "KRWA9" $=20.82 \mathrm{~g}$ and "Cook" $=21.62 \mathrm{~g}$ ) which were statistically different from the means of 1000 kernel weight of the DC $F_{2: 3}$ progenies $(31.52 \mathrm{~g})$. This suggested that the RWA and the "Ug99" (Sr36) resistance genes present in $\mathrm{DC} \mathrm{F}_{2: 3}$ were expressed and played a major role in preventing reduction in 1000 kernel weight by both the RWA and the stem rust race "Ug99". Data on stem rust severity and RWA damage index (Figure 1) showed that the $\mathrm{DC} \mathrm{F}_{2: 3}$ had moderate resistance to RWA and stem rust which contributed to the high 1000 kernel weight.
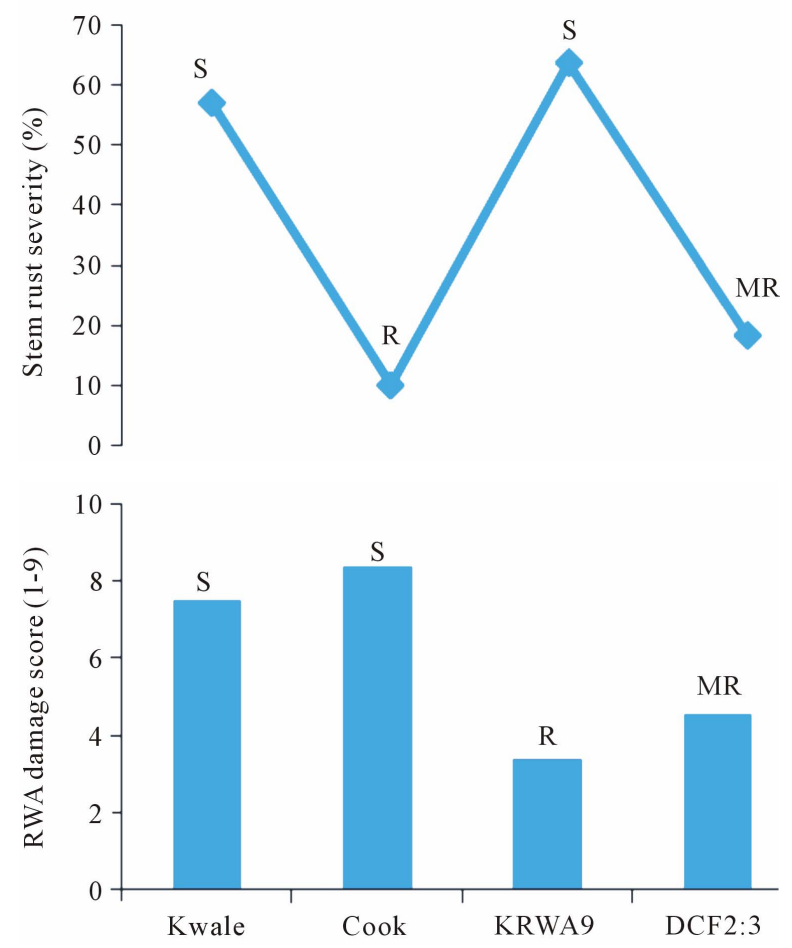

Figure 1. Stem rust severity index (above) and RWA damage index (below) recorded on "Kwale", “Cook”, “KRWA9" and DC $F_{2: 3}$ during open field yield evaluation trial.

The 1000 kernel weight of parent "Kwale" was much lower than the other two parents ("KRWA9" and "Cook"), a difference that could be attributed to several factors, among them, continuous high infestation by RWA and "Ug99" because "Kwale" lacks both RWA and "Ug99" resistance (Figure 1) while at least one of the genes is present in "KRWA9" and "Cook". "KRWA9" carries a single dominant RWA resistance gene $[5,11,26]$ and "Cook" carries "Ug99" resistance gene Sr36 [27]. Another factor that could have led to the pronounced reduction in 1000 kernel weight of the variety "Kwale" is that it has a long maturing period compared to "KRWA9" and "Cook" (Table 2). This allowed it to be infested/ infected long after other varieties were dry.

It is worth noting that "Ug99" caused more kernel weight reduction than the Russian wheat aphid (Table 1); the reduction in 1000 kernel weight of "KRWA9", which lacks "Ug99" resistance gene, was significantly greater than the reduction in kernel weight of "Cook", which lacks RWA resistance gene. This conforms to previous reports indicating that yield losses due to "Ug99" are greater, up to $100 \%$ [18] compared to losses due to RWA, up to $90 \%$ [6].

\subsection{Kernel Weight/Spike}

This yield component is important in wheat because 
Table 1. Means for 1000 kernel weight, weight of kernel/spike, number of effective tillers/plant and yield (t/ha) of the three parents and DC $\mathbf{F}_{2: 3}$.

\begin{tabular}{ccccc}
\hline \multirow{2}{*}{ Germplasm } & \multicolumn{3}{c}{ Means } \\
\cline { 2 - 5 } & 1000 Kernel Weight (g) & Weight of kernel/spike (g) & Number of effective tillers/plant & Yield (t/ha) \\
\hline Kwale & $17.73 \mathrm{a}$ & $0.98 \mathrm{a}$ & $4.30 \mathrm{~b}$ & $0.282 \mathrm{a}$ \\
Cook & $21.62 \mathrm{~b}$ & $1.22 \mathrm{a}$ & $3.17 \mathrm{a}$ & $0.340 \mathrm{~b}$ \\
KRWA9 & $20.82 \mathrm{~b}$ & $1.16 \mathrm{a}$ & $5.67 \mathrm{c}$ & $0.296 \mathrm{a}$ \\
DC F F:3 & $31.52 \mathrm{c}$ & $2.24 \mathrm{~b}$ & $4.20 \mathrm{~b}$ & $0.589 \mathrm{c}$ \\
C.V. (\%) & 3.80 & 14.50 & 3.40 & 4.30 \\
L.S.D. (0.05) & 1.736 & 0.407 & 0.296 & 0.032 \\
\hline
\end{tabular}

Means within columns followed by the same letter are not significantly different $(\mathrm{P}<0.05)$.

Table 2. Means for RWA severity damage, stem rust severity, days to $50 \%$ flowering and days to maturity of Kwale, Cook, KRWA9 and DC $F_{2: 3}$ population.

\begin{tabular}{ccccc}
\hline \multirow{2}{*}{ Germplasm } & \multicolumn{3}{c}{ Means } \\
\cline { 2 - 5 } & RWA severity damage $(1-9)$ & Stem rust severity (\%) & Days to $50 \%$ flowering & Days to maturity \\
\hline Kwale & $7.47 \mathrm{a}$ & $57.00 \mathrm{a}$ & $78.33 \mathrm{a}$ & $128.33 \mathrm{a}$ \\
Cook & $8.36 \mathrm{a}$ & $10.00 \mathrm{~b}$ & $63.00 \mathrm{c}$ & $107.00 \mathrm{c}$ \\
KRWA9 & $3.33 \mathrm{~b}$ & $63.70 \mathrm{a}$ & $60.67 \mathrm{c}$ & $105.33 \mathrm{c}$ \\
DC F 2:3 $_{\text {C.V. }(\%)}$ & $4.50 \mathrm{~b}$ & $18.30 \mathrm{~b}$ & $67.33 \mathrm{~b}$ & $114.67 \mathrm{~b}$ \\
L.S.D. (0.05) & 14.50 & 14.00 & 2.00 & 1.00 \\
\hline
\end{tabular}

Means within columns followed by the same letter are not significantly different $(\mathrm{P}<0.05)$.

spike weight is associated with kernel number. The results of weight of kernel/spike of the three parents and the DC $\mathrm{F}_{2: 3}$ are presented in Table 1. Generally, the DC $\mathrm{F}_{2: 3}$ recorded a significantly higher mean weight of kernel/spike $(2.24 \mathrm{~g})$ compared to the parental cultivars ("Kwale" $=0.98 \mathrm{~g}$, "KRWA9" = $1.16 \mathrm{~g}$ and "Cook" = $1.22 \mathrm{~g}$ ). This high weight of kernel/spike could be attributed to the presence of both RWA and "Ug99" resistance genes in the $\mathrm{DC} \mathrm{F}_{2: 3}$ (Figure 1) which contributed to the reduction of insect (RWA) and disease ("Ug99") pressure. Another factor that could have contributed to the higher mean weight of kernel/spike was the earliness in maturity of the $\mathrm{DC}_{2: 3}$ (Table 2) which allowed very little time for the buildup of stem rust, a form of disease escape as [28], hence minimal crop damage.

There was no significant difference in the mean weight of kernel/spike between the three parents "Kwale", "KRWA9" and "Cook". However, "Kwale" recorded the lowest mean weight of kernel/spike, probably because it was most affected by both RWA and "Ug99" as it is known to be susceptible to the two pests (Figure 1). The lateness in maturity of "Kwale" (Table 2) might have also contributed to the lowest mean weight of kernel/ spike since it allowed more time for infestation/infection of RWA and "Ug99" leading to a lot of crop damage.

\subsection{Effective Tillers/Plant}

The mean number of effective tillers/plant of the three parents and the $\mathrm{DC} \mathrm{F}_{2: 3}$ is presented in Table 1. The data indicates that parent "KRWA9" recorded a significantly higher mean number (5.67) of effective tillers/plant compared to the other two parents and the $\mathrm{DC} \mathrm{F}_{2: 3}$. This corroborates previous reports that "KRWA9" produces a lot more tillers $[5,10]$. These results also agree with Lage et al., [29], who reported that RWA feeding on a tolerant variety stimulates tillering and stem elongation. On the other hand there was no significant difference between the mean number of effective tillers/plant of the parent "Kwale" (4.3) and the DC $\mathrm{F}_{2: 3}$ progenies (4.2). This could be attributed to the fact that "Kwale" was used as a female parent in both the initial single crosses, i.e. "Kwale $\times$ Cook" and "Kwale $\times$ KRWA9", which could 
have led to a cytoplasmic inheritance [30]. In this case the DC $\mathrm{F}_{2: 3}$ progenies might have inherited most characters from the parent "Kwale", the rate of tillering being one of them. Cytoplasmic inheritance is controlled by a small minority genes located outside the nucleus i.e. in organelles in the cytoplasm (cytoplasmic genes). The genes concerned might be located in the chloroplasts or mitochondria within the cytoplasm, and are therefore transmitted through the female parent.

The parent "Cook" recorded a significantly low mean number $(\sim 3)$ of effective tillers/plant. This was probably because "Cook", being an Australian variety, is not well adapted to the Kenyan environment hence its growth and development could have been compromised. The number of effective tillers/plant is an important yield component in wheat because in most cases the higher the rate of tillering of a plant, the higher the number of spikes produced and hence the higher the grain yield.

\subsection{Grain Yield}

Data on mean grain yield (tons/ha) of the three parents and the $\mathrm{DC} \mathrm{F}_{2: 3}$ progenies is presented in Table 1. Overall, all the parents recorded significantly lower grain yields ("Kwale $=0.282 \mathrm{t} / \mathrm{ha}$, "Cook" $=0.340 \mathrm{t} / \mathrm{ha}$ and "KRWA9" $=0.296 \mathrm{t} / \mathrm{ha}$ ) compared to the mean grain yield of the $\mathrm{DC} \mathrm{F}_{2: 3}$ progenies $(0.589 \mathrm{t} / \mathrm{ha})$. This indicated a successful introgression of the RWA and the "Ug99" resistance genes in the DC $\mathrm{F}_{2: 3}$ progenies (Figure 1), the expression of which played a major role in preventing grain yield losses by providing protection against both RWA and "Ug99".

The mean grain yield of "Kwale" was much lower than that of the other two parents ("Cook" and "KRWA9"), a difference that could be attributed to continual infestation by RWA and high "Ug99" pressure since it lacks both RWA and "Ug99" resistance (Figure 1). As earlier alluded, other factors including its long maturing period (Table 2) would have allowed more time for RWA and "Ug99" damage, hence low yield. The grain yield data also affirmed that the yield losses due to "Ug99" were greater than yield losses caused by RWA. Though the $\mathrm{DC} \mathrm{F}_{2: 3}$ progenies recorded significantly higher grain yield compared to the parents, the grain yield did not reach the average grain yield of wheat (3 - 4 $\mathrm{t} / \mathrm{ha}$ ) in Kenya. This is probably because only one race of stem rust, TTKSK ("Ug99"), was targeted; the other new races such as TTTSK and TTKST were not addressed and could have contributed to the lowered grain yield recoded. Additionally, the effect of genetic noise from the parents during development of the new germplasm cannot be overlooked. This could be the reason for the yield tradeoffs expressed in the new germplasm when compared to the recorded yield of commercial cultivars grown in Kenya.

In conclusion, this study has indicated that gene pyramiding for tolerance/resistance to both RWA and stem rust in a single germplasm can provide lines with acceptable yield while achieving resistance to the two problematic pests. This should provide the impetus to pursue breeding of durable resistance for these wheat pests in the Kenyan breeding programmes.

\section{Acknowledgements}

We thank the Kenya Agricultural Research Institute (KARI)-Njoro for the space, facilities and technical support they provided during the entire research period. We also acknowledge the financial support of Murdoch University through Professor Mehmet Cakir. Extra funding was also obtained from Egerton University through the graduate student research fund to FOA.

\section{REFERENCES}

[1] O. V. Kovalev, T. J. Poprawski, A. V. Stekolshchikov, A. B. Vereshchagina and S. A. Gandrabur, "Diuraphis Aizenberg (Hom. Aphididae); Key Apterous Viviparous Females, and Review of Russian Literature on the Natural History of Diuraphis noxia (Kurdjumov, 1913)," Journal of Applied Entomology, Vol. 112, 1991, pp. 425-436. doi:10.1111/j.1439-0418.1991.tb01076.x

[2] J. Webster, S. Amosson, L. Brooks, G. Hein, G. Johnson, D. Legg, W. Massey, P. Morrison, F. Peairs and M. Weiss, "Economic Impact of the Russian Wheat Aphid in the Western United States: 1992-1993," Great Plains Agricultural Council Publication, 1994, p. 152.

[3] P. H. Hewitt, "The South African Experience with the Russian Wheat Aphid, 1-3," In: F. B. Peairs and S. D. Pilcher, Eds., Proceedings 2nd Russian Wheat Aphid Workshop, Colorado State University, Fort Collins, 1988.

[4] M. Macharia, P. M. Muthangya and J. K. Wanjama, "Response to Seed-Dressing Aphicides in Commercial Varieties Russian Wheat Aphid (Diuraphis noxia) Damage in Kenya," Proceedings of the 10th Regional Wheat Workshop for Eastern, Central and Southern Africa, Pretoria University, Pretoria, 1999, pp. 418-421.

[5] J. N. Maling'a, "Studies on Russian Wheat Aphid (Diuraphis noxia Kurdjumov) with Special Emphasis to Biotypes and Host Plant Resistance in Bread Wheat (Triticum aestivum L.) in Kenya," Ph.D. Thesis, Egerton University, Njoro, 2007.

[6] M. Kinyua, J. Maling'a, L. Karanja and J. Wanjama, “Application of Biotechnology in Development of Bread Wheat Varieties Resistant/Tolerant to Russian Wheat Aphid (Diuraphis noxia)," Proceedings of the 7th KARI Biennial Scientific Conference, Collaborative and Participatory Research for Sustainable Improved Livelihoods, 13-17 November 2000.

[7] J. P. Michaud and P. E. Sloderbeck, "Russian Wheat Aphid: An Introduced Pest of Small Grains in the High 
Plains," Kansas State University Press, Lawrence, 2005.

[8] N. L. V. Lapitan, "Fractionated Extracts of Russian Wheat Aphid Eliciting Defense Responses in Wheat," Journal of Economic Entomology, Vol. 100, No. 3, 2007, pp. 990-999.

doi:10.1603/0022-0493(2007)100[990:FEORWA]2.0.CO $\underline{2}$

[9] J. N. Maling'a, M. G. Kinyua, A. W. Kamau, J. K. Wanjama, J. O. Awalla and R. S. Pathak, "Biotypic and Genetic Variation within Tropical Populations of Russian Wheat Aphid, Diuraphis noxia (Kurdjumov) (Homoptera: Aphididae) in Kenya," Journal of Entomology, Vol. 4, No. 5, 2007, pp. 350-360. doi:10.3923/je.2007.350.361

[10] R. S. Pathak, K. J. Kenduiwa, M. G. Kinyua and J. N. Maling'a, "Evidence of Duplicate Gene Loci for Resistance to Russsian Wheat Aphid (Duiraphis noxia Mordvilko) in Bread Wheat," Proceedings of African Crop Science, Vol. 8, 2007, pp. 703-708.

[11] K. Kenduiwa, "Genetics of Resistance to Russian Wheat Aphid (Diuraphis noxia Mordvilko) in Bread Wheat (Triticum aestivum L.)," MSc. Thesis, Egerton University, Njoro, 2009.

[12] J. Berner, "Biochemistry of Russian Wheat Aphid Resistance in Wheat: Involvement of Lipid-Like Products," Ph.D. Thesis, Department of Plant Sciences, Faculty of Natural and Agricultural Sciences, University of the Free State Bloemfontein, 2006.

[13] V. L.Tolmay, "Genetic Variability for Russian Wheat Aphid, Diuraphis noxia Resistance in South African Wheat Genotypes," Ph.D. Thesis, University of the Free State, Bloemfontein, 2006.

[14] M. C. Walters, "Progress in Russian Wheat Aphid (Diuraphis noxia Mordw.) Research in the Republic of South Africa," Proceedings of a Meeting of the Russian Aphid Task Team, University of the Orange Free State, Bloemfontein, 5-6 May 1982.

[15] J. L. Kurt, "Black Stem Rust Biology and Threat to Wheat Growers, U.S. Department of Agriculture," Report to the Central Plant Board Meeting, Lexington, 5-8 February 2001.

[16] CIMMYT, "Sounding the Alarm on Global Stem Rust. An Assessment of Ug99 in Kenya and Ethiopia and Potential for Impact in Neighboring Regions and Beyond," CIMMYT Circular, 29 May 2007.

[17] R. Wanyera, M. G. Kinyua, Y. Jin and R. P. Sing, "The Spread of Stem Rust Caused by Puccinia graminis f.sp. Tritici, with Virulence on Sr31 in Wheat in Eastern Africa," Plant Disease, Vol. 90, No. 1, 2006, p. 113. doi:10.1094/PD-90-0113A

[18] D. Hildebrant, "Future World Wheat Crops Threatened by Ug99 Stem Rust," Farm and Ranch Guide, 2008.

[19] CIMMYT, "Sounding the Alarm on Global Wheat Rust,"
CIMMYT, Mexico City, 2005.

http://www.globalrust.org/uploads/documents/SoundingA larmGlobalRust.pdf

[20] R. P. Singh, D. P. Hodson, J. Huerta-Espino and M. Kinyua, "Will Stem Rust Destroy the World's Wheat Crop? Advances in Agronomy, Vol. 98, 2008, pp. 271309. doi:10.1016/S0065-2113(08)00205-8

[21] R. P. Singh, D. P. Hodson, Y. Jin, J. Huerta-Espino and M. Kinyua, "Current Status, Likely Migration and Strategies to Mitigate the Threat to Wheat Production from Race Ug99 (TTKS) of Stem Rust Pathogen," CAB Reviews: Perspectives in Agriculture, Veterinary Science, Nutrition and Natural Resources, Vol. 1, No. 54, 2006, pp. 1-13. doi:10.1079/PAVSNNR20061054

[22] J. Ellis, R. Mago, R. Kota, P. Dodds, H. McFadden, G. Lawrence, W. Spielmeyer and E. Lagudah, "Wheat Rust Resistance Research at CSIRO," Australian Journal of Agricutural Research, Vol. 58, No. 6, 2007, pp. 607-511. doi:10.1071/AR06151

[23] I. A. Dundas, D. C. Verlin, R. F. Park, H. S. Bariana, D. R. Anugrahwati, R. Mago and A. K. M. R. Islam, "New Sources of Rust Resistance from Alien Species: Meliorating Linked Defects and Discovery," Australian Journal of Agricutural Research, Vol. 58, No. 6, 2007, pp. 545549. doi:10.1071/AR07056

[24] R. P. Singh, D. P. Hodson, J. Huerta-Espino, Y. Jin, S. Bhavani, P. Njau, S. Herrera-Foessel, P. K. Singh, S. Singh and V. Govindan, "The Emergence of Ug99 Races of Stem Rust Fungus Is a Threat to World Wheat Production," Annual Review of Phytopathology, Vol. 49, 2011, pp. 465-681. doi:10.1146/annurev-phyto-072910-095423

[25] R. Jaetzold and H. Schmidt, "Farm Management Handbook of Kenya, Vols. 2 B Central Kenya (Rift Valley and Central Provinces)," Ministry of Agriculture in Cooperation with GAT of GTZ, Nairobi, 2007.

[26] R. S. Pathak, J. N. Maling'a, M. G. Kinyua, J. K. Wanjama and A. W. Kamau, "Genes for Resistance to Russian Wheat Aphid to Two New Wheat Lines," 4th International Crop Science Congress, Maputo, 2004.

[27] R. P. Singh, D. P. Hodson, Y. Jin, J. Huerta-Espin, M. G. Kinyua, R. Wanyera, P. Njau and R. W. Ward, "Current Status, Likely Migration and Strategies to Mitigate the Threat to Wheat," 2006.

[28] R. H. Painter, "Insect Resistance in Crop Plants," Macmillan, New York, 1951.

[29] J. Lage, B. Skonvamand and S. B. Anderson, "Resistance Categories of Synthetic Hexaploid Wheat Resistant to the Russian Wheat Aphid (Diuraphis noxia)," Euphytica, Vol. 136, No. 3, 2004, pp. 291-296. doi:10.1023/B:EUPH.0000032732.53350.93

[30] D. L. Hartl and A. G. Clark, "Principles of Population Genetics," 4th Edition, Macmillan, New York, 2007. 